\title{
Production and characteristics of fish protein hydrolysate from parrotfish (Chlorurus sordidus) head
}

\author{
Asep A Prihanto ${ }^{\text {Corresp., } 1,2}$, Rahmi Nurdiani ${ }^{1,2}$, Annas D Bagus ${ }^{2}$ \\ ${ }^{1}$ Department of Fishery Product Technology, Faculty of Fisheries and Marine Science, Brawijaya University, Malang, East Java, Indonesia \\ 2 BIO-SEAFOOD Research Unit, Brawijaya University, Malang, East Java, Indonesia \\ Corresponding Author: Asep A Prihanto \\ Email address: asep_awa@ub.ac.id
}

Background. Fish byproducts are commonly recognized as low-value resources. In order to increase the value, fish byproducts need to be converted into new products with high functionality such as fish protein hydrolysates (FPH). In this study, FPH manufactured from parrotfish (Chlorurus sordidus) heads using different $\mathrm{pH}$, time and sample ratio was investigated. Methods. Hydrolysis reactions were conducted under different $\mathrm{pHs}(5,7$, and 9) and over different durations (12 and $24 \mathrm{~h}$ ). Control treatment (without pH adjustment ( $\mathrm{pH}$ 6.4)) and $0 \mathrm{~h}$ hydrolsisis duration were applied. Hydrolysates were characterized with respect to proximate composition, amino acid profile, and molecular weight distribution. The antioxidant activity of the hydrolysate was also observed.

Results. The $\mathrm{pH}$ and duration of hydrolysis significantly affected $(p<0.05)$ the characteristics of FPH. The highest yield of hydrolysate $(49.04 \pm 0.90 \%)$, with a degree of hydrolysis (DH) of $30.65 \pm 1.82 \%$, was obtained at $\mathrm{pH} 9$ after $24 \mathrm{~h}$ incubation. In addition, the FPH had high antioxidant activity $(58.20 \pm 0.55 \%)$, with a high level of essential amino acids. Results suggested that FPH produced using endogenous enzymes represents a promising additive for food and industrial applications. 
1 Production and characteristics of fish protein 2 hydrolysate from parrotfish (Chlorurus sordidus) head 3 4

5 Asep Awaludin Prihanto ${ }^{1,2}$, Rahmi Nurdiani ${ }^{1,2}$, Annas Dwi Bagus ${ }^{2}$ 6

$7 \quad{ }^{1}$ Department of Fishery Product Technology, Faculty of Fisheries and Marine Science,

8 Brawijaya University, Malang East Java, Indonesia

$9 \quad{ }^{2}$ Bio-Seafood Research Unit, Brawijaya University, Malang, East Java, Indonesia. 10

11 Corresponding Author:

12 Asep Awaludin Prihanto ${ }^{1}$

13 Faculty of Fisheries and Marine Science, Brawijaya University Jl. Veteran, Malang, East Java, 1465145 , Indonesia 


\section{Abstract}

21 Background. Fish byproducts are commonly recognized as low-value resources. In order to increase the value, fish byproducts need to be converted into new products with high

23 functionality such as fish protein hydrolysates (FPH). In this study, FPH manufactured from

24 parrotfish (Chlorurus sordidus) heads using different $\mathrm{pH}$, time and sample ratio was investigated.

25 Methods. Hydrolysis reactions were conducted under different $\mathrm{pHs}$ (5, 7, and 9) and over

26 different durations (12 and $24 \mathrm{~h}$ ). Control treatment (without $\mathrm{pH}$ adjustment ( $\mathrm{pH} 6.4$ )) and $0 \mathrm{~h}$

27 hydrolsisis duration were applied. Hydrolysates were characterized with respect to proximate

28 composition, amino acid profile, and molecular weight distribution. The antioxidant activity of

29 the hydrolysate was also observed.

30 Results. The $\mathrm{pH}$ and duration of hydrolysis significantly affected $(\mathrm{p}<0.05)$ the characteristics of

31 FPH. The highest yield of hydrolysate $(49.04 \pm 0.90 \%)$, with a degree of hydrolysis (DH) of

$3230.65 \pm 1.82 \%$, was obtained at $\mathrm{pH} 9$ after $24 \mathrm{~h}$ incubation. In addition, the FPH had high

33 antioxidant activity (58.20 $\pm 0.55 \%)$, with a high level of essential amino acids. Results suggested

34 that FPH produced using endogenous enzymes represents a promising additive for food and

35 industrial applications.

36

37

38 
39

40

41

42

43

44

45

46

47

48

49

50

51

52

53

54

55

56

57

58

59

60

61

62

63

64

65

66

67

68

69

70

71

72

73

74

75

76

77

78

\section{Introduction}

Parrotfish (Chlorurus sordidus) are one of the most important fish commodities in Indonesia (Adrim, 2010). Parrotfish have unique and exceptional arrangements of teeth and body shape (Chen, 2002). The data In 2014, parrotfish fishing production increased by $18.8 \%$ (76 tons) compared to all reef fish fisheries in the Asian region (FAO, 2015). In Indonesia, a total of 1,8 ton parrotfish production was recorded for 2019 (Ministry of Marine Affair and Fisheries, 2019). An increase in the number of catch means an increase in the amount of byproduct processing, as processing requires the removal of bones, skin, head, scales, and viscera. Out of all the other body parts, the head accounts for approximately $19 \%$ of the total fish processing-byproducts from fillet processing (Anil, 2017). Several parts of by product such as scales and bone was applied as gelatin (Herpandi, Huda, \& Adzitey, 2019). In contrast, fish head was still underutilized.

Fish byproducts, commonly recognized as low-value resources, can be further developed into products with high economic value if handled and processed appropriately (Hapsari \& Welasi, 2013). In general, fish byproducts contain many elements, such as nitrogen, phosphorus, potassium, and others, which are the constituents of proteins and fats (Lepongbulan et al., 2017). Thus, the protein fraction of byproducts can be utilized for the production of fish protein hydrolysate (FPH) with desirable functionality. In addition, FPH has reported to exhibit bioactive properties, such as antihypertensive, antioxidant (Yang et al. 2011), antithrombotic (Qiao et al. 2018), anticancer, and immunomodulatory activities (Kim \& Mendis 2006). FPH can be manufactured from the decomposition of fish proteins into simple peptides (2-20 amino acids) through hydrolysis by adding enzymes, acids, or bases (Nurilmala, Nurhayati \& Roskananda, 2018). The characteristics and quality of FPH are highly influenced by several factors, including the type of proteases or chemicals used, temperature, $\mathrm{pH}$, and duration of hydrolysis (Nazeer \& Kulandai, 2012).

In previous studies, FPH was developed using various fisheries byproducts, including cod head waste (Himonides Taylor \& Morris, 2011), catfish (Nurilmala, Nurhayati \& Roskananda, 2018), tuna (Bougatef et al., 2012; Herpandi, Huda, \& Adzitey, 2019), Sardinella (Jeevitha, Priya \& Khora, 2014), and tilapia (Srikanya et al., 2017). Nevertheless, the production of FPH from parrotfish byproducts remains limited. This study aimed to determine the characteristics of protein hydrolysates from parrotfish (C. sordidus) heads, extracted at different $\mathrm{pHs}$ and hydrolysis duration periods.

\section{Materials \& Methods Materials}

All materials used in this experiment were of analytical grade and were purchased from Merck (Darmstadt-Germany) (USA). Parrotfish (C. sordidus) heads with the average weight of $250 \pm$ 18 gr were obtained from a local fish processing plant (PT. Alam, Surabaya). The heads were transported to the laboratory using a storage box maintained at $4^{\circ} \mathrm{C}$. 


\section{Preparation of fish protein hydrolysate}

80 Preliminary experiments on the optimum water: substrate ratios were conducted to obtain the 81 highest yield and antioxidant activity of hydrolysate. Fish heads were crushed in Philips-Food 82 Processor, model HR7627, 650 watt, capacity $2.1 \mathrm{~L}$. Briefly, $20 \mathrm{~g}$ of minced fish head was mixed 83 with $\mathrm{dH}_{2} \mathrm{O}$ in ratios of 1:0, 1:1,1:2, and 1:3 (w/v). Hydrolysis for $18 \mathrm{~h}$ was conducted using an 84 orbital shaker at $150 \mathrm{rpm}$ at temperature of $30 \pm 2{ }^{\circ} \mathrm{C}$. Next, the mixture was centrifuged at 3000 85 86 87

Where $\mathrm{A}=$ final weight of hydrolysate (after centrifugation) $(\mathrm{g})$, and $\mathrm{B}=$ initial weight of the sample after mixing (before incubation) $(\mathrm{g})$.

\section{Antioxidant assay (DPPH radical scavenging activity)}

The antioxidant activity of FPH was examined according to a modified protocol described by Donkor et al., (2012). As much as $100 \mu \mathrm{L}$ of liquid protein was added to $3900 \mu \mathrm{L} 0.075 \mathrm{mM} 2,2-$ Diphenyl-1-picrylhydrazyl (DPPH) in 95\% methanol; the mixture was kept in the dark for $1 \mathrm{~h}$. The absorbance value of the solution was measured at a wavelength of $517 \mathrm{~nm}$ using an ultraviolet-visible (UV-Vis) spectrophotometer. Antioxidant activity was calculated using the following equation: 


$$
\% \text { antioxidant activity }=\left[\frac{\text { blank absorbance }- \text { sample absorbance }}{\text { blank absorbance }}\right] \times 100 \%
$$

119

120

121

122

123

124

125

126

127

128

129

130

131

132

133

134

135

136

137

138

139

140

141

142

143

144

145

146

147

148

149

150

151

152

153

154

\section{Proximate analysis}

Protein, fat, water content, and ash analyses were performed according to the method described by $A O A C$ (2005). Protein was analyzed following the Kjeldahl method, and fat was analyzed using the Soxhlet method. Ash was determined by heating the samples in a furnace at $550^{\circ} \mathrm{C}$ for 8-12 h.

\section{Degree of hydrolysis (DH)}

A slightly modified method of that described by Hoyle \& Merritt, (1994) was employed for the DH analysis. Liquid FPH (2 mL) was combined with Trichloroacetic acid (TCA) 20\% (v/v); the aliquot was left for $30 \mathrm{~min}$ prior to centrifugation $(5000 \mathrm{rpm}, 30 \mathrm{~min}$ ). The supernatant was decanted and analyzed for nitrogen content following the Kjeldahl method (AOAC, 2005). DH was calculated using the following formula:

$$
\text { Degree of Hydrolysis }(\mathrm{DH})=\frac{\mathrm{TCA}-\text { soluble nitrogen }}{\text { Total nitrogen in sample }} \times 100 \%
$$

\section{Molecular weight analysis (SDS-PAGE)}

FPH molecular weight was determined by sodium dodecyl sulfate-polyacrylamide gel electrophoresis (SDS-PAGE), based on the Laemmli method (Laemmli, 1970). SDS-PAGE analysis utilized a 12\% separating gel and 4\% stacking gel. Mixed samples and loading buffers, as much as $30 \mu \mathrm{L}$, were run at $20 \mathrm{~mA}$ and $100 \mathrm{~V}$ for $3 \mathrm{~h}$. The gel was then stained with staining solution Coomassie Brilliant Blue (CBB) R-250 $1 \mathrm{~g}$, methanol $450 \mathrm{~mL}$, glacial acetic acid 100 $\mathrm{mL}$, and distilled water $450 \mathrm{~mL}$ ). The stained gel was subsequently de-stained using the same solution without CBB R-250.

\section{Free amino acid analysis}

FPH free amino acid profiles were determined according to a slightly modified method of that described by Boogers et al., (2008). Ultra-High Performance Liquid Chromatography (UPLC), using an Acquity system (Waters), was utilized for free amino acid analysis. Sample (0.50 mL) was pipetted into a $100 \mathrm{~mL}$ volumetric flask, and $2.0 \mathrm{~mL}$ of alpha amino butyric acid (AABA) $10 \mathrm{mM}$ internal standard solution was added. The solution was diluted to the limit mark with 0.1 $\mathrm{N} \mathrm{HCl}$, before being homogenized. Next, the solution was filtered through a $0.22 \mu \mathrm{m}$ membrane filter. Ten microliters of the solution was added to $70 \mu \mathrm{L}$ of AccQ-Fluor Borate. After that, up to $20 \mu \mathrm{L}$ fluorine reagent A was added, before being vortexed, and allowed to stand for $1 \mathrm{~min}$. One microliter of sample solution was injected into the UPLC system (ACCQ-Tag Ultra C18, fluid rate system of $0.7 \mathrm{~mL}$ per minute, the column temperature was maintained at $55^{\circ} \mathrm{C}$, and a photodiode array detector at a wavelength of $260 \mathrm{~nm}$ ). 
155

156

157

158

159

160

161

162

163

164

165

166

167

168

169

170

171

172

173

174

175

176

177

178

179

180

181

182

183

184

185

186

187

188

189

190

191

192

193

\section{Statistical Analysis}

All data and RSM optimizations were analyzed by using Minitab 18 Statistical software (Minitab Pty Ltd. Australia). Except data for optimization, all data obtained were subjected to one-way analysis of variance, followed by post-hoc test (Tukey analysis). Data are presented as the mean from three independent experiment $\pm \mathrm{SD}$ of the results.

\section{Results}

\section{Proximate composition of parrotfish heads}

The proximate composition of minced parrotfish (C. sordidus) heads is listed in Table 1. The protein content, at 20.37 $\pm 2.33 \%$, was higher than salmon and Mackarel head. The fat content (3.92 \%) was slightly higher than Mackarel fish 3.70\%, and far lower than salmon (17.4\%). The water content $(71.68 \pm 2.33 \%)$ was higher than that of salmon (65.9\%) but lower Mackarel fish ( $65.9 \%$ ).

Table 1: insert here..

\section{Fish Protein Hydrolysate (FPH) from parrotfish heads}

Five layers were formed after centrifugation. The first layer was oil/fat, followed by light lipoprotein, soluble protein, fine particles, and coarse particles layers (Fig. 1A). Soluble protein layers were carefully separated and collected (Fig. 1B). The yield and antioxidant activity of liquid/soluble protein were measured. The soluble protein layer was also spray-dried (Fig. 1C). Figure 1: insert here..

\section{Effect of substrate: water ratio on the yield and antioxidant activity of soluble protein}

The ratio of minced head: $\mathrm{dH}_{2} \mathrm{O}$ significantly affected $(\mathrm{p}<0.05)$ the yield and antioxidant activity of the FPH produced, as seen in Fig. 2. Among the four ratios $(1: 0,1: 1,1: 2$, and 1:3), the highest yield and antioxidant activity were obtained from the ratio of $1: 2(\mathrm{w} / \mathrm{v})$, with values of $42.70 \pm 0.70$ and $51.50 \pm 0.90 \%$, respectively. The ratio of 1:0 generated the lowest yield and antioxidant activity.

Figure 2: insert here..

\section{Effect of $\mathrm{pH}$ and hydrolysis duration on FPH characteristics}

The characteristics of FPH from parrotfish head hydrolyzed at various $\mathrm{pH}$ and time durations are shown in Table 2.

Table 2: insert here..

\section{Yield of FPH}


194

195

196

197

198

199

200

201

202

203

204

205

206

207

208

209

210

211

212

213

214

215

216

217

218

219

220

221

222

223

224

225

226

227

228

229

230

231

232

Yields of FPH ranged from $4.96 \pm 0.72 \%$ to $49.0 \pm 0.9 \%$. The highest yield $(49.0 \pm 0.9 \%)$ was obtained at $\mathrm{pH} 9$ after $24 \mathrm{~h}$ of hydrolysis The lowest yield $(4.96 \pm 0.72 \%)$ was obtained at $\mathrm{pH} 7$ and $0 \mathrm{~h}$ of hydrolysis. The result suggested that $\mathrm{pH}$, duration of hydrolysis, and its interaction significantly affected the yield $(\mathrm{p}<0.05)$.

\section{Antioxidant activity}

The highest antioxidant activity $(58.20 \pm 0.55 \%)$ was obtained after 24 h hydrolysis at $\mathrm{pH} 9$. FPH showed the lowest antioxidant activity $(5.69 \pm 4.57 \%)$ at $\mathrm{pH} 9$ and $0 \mathrm{~h}$ of hydrolysis. Both $\mathrm{pH}$ and duration of hydrolysis significantly affected the antioxidant activity $(\mathrm{p}<0.05)$.

\section{Proximate composition}

$\mathrm{pH}$ and hydrolysis time significantly affected $(\mathrm{p}<0.05)$ all proximate parameters. The highest protein content $(69.15 \pm 1.11 \%)$ was obtained at $\mathrm{pH} 9$, with $24 \mathrm{~h}$ of hydrolysis time. The fat content of parrotfish head FPH ranged from $0.68 \pm 0.13 \%$ to $5.882 .99 \%$; the highest fat content was obtained at $\mathrm{pH} 5$ with $0 \mathrm{~h}$ of hydrolysis time and the lowest fat content was obtained at $\mathrm{pH} 9$ with $24 \mathrm{~h}$ of hydrolysis time.

The ash content of the FPH of parrotfish head ranged from $4.55 \pm 0.35 \%$ to $8.60 \pm 0.78 \%$; the highest ash content was obtained at $\mathrm{pH} 9$ with a $12 \mathrm{~h}$ hydrolysis time, while the lowest was observed in the control treatment ( $\mathrm{pH} 6.4)$ with a $12 \mathrm{~h}$ hydrolysis time $(4.60 \pm 0.35 \%)$. ANOVA analysis revealed that different $\mathrm{pH}$ treatments resulted in significantly different results $(\mathrm{p}<0.05)$. The water content of the parrotfish FPH ranged from $7.25 \pm 1.06 \%$ to $9.01 \pm 0.71 \%$; the highest water content was obtained at $\mathrm{pH} 9$ with a $12 \mathrm{~h}$ hydrolysis time $(9.01 \pm 0.71 \%)$, while the lowest water content was obtained at $\mathrm{pH} 7$ with a 24 h hydrolysis time $(7.25 \pm 1.06 \%)$.

\section{Degree of Hydrolysis (DH)}

The essential properties of FPH rely on the DH of the process. A high DH can be used as an indicator of effective hydrolysis. The result of $\mathrm{DH}$ analysis ranged from $0.26 \pm 0.11 \%$ to $30.65 \pm 1.82 \%$. The highest DH was observed at pH 9 after 24 h hydrolysis, while the lowest DH was obtained at $\mathrm{pH} 7$ after $2 \mathrm{~h}$ hydrolysis. Both $\mathrm{pH}$ and duration of hydrolysis significantly affected $(\mathrm{p}<0.05) \mathrm{DH}$.

\section{Optimum conditions for preparation of FPH}

The optimum conditions for parrotfish FPH production were analyzed using the RSM, based on the yield, antioxidant activity, protein, fat, water, ash, and DH of the FPH. The overlaid contour plot as a result of RSM analysis is shown in Fig. 3.

Figure 3: insert here..

Based on Figure 3, it was apparent that $\mathrm{pH}$ 8-9 and 21.5-24 h of hydrolysis were considered the optimum conditions for producing FPH. As the longer hydrolysis time gave better FPH 
233 characteristics, $\mathrm{pH} 9$ and $24 \mathrm{~h}$ hydrolysis were considered the optimum conditions for generating

234

235

236

237

238

239

240

241

242

243

244

245

246

247

248

249

250

251

252

253

254

255

256

257

258

259

260

261

262

263

264

265

266

267

268

269

270

271

272

FPH with the best characteristics from the head byproduct of parrotfish.

\section{SDS-PAGE analysis}

SDS-PAGE analysis was carried out to observe the molecular weight range of the FPH obtained under optimum conditions ( $\mathrm{pH} 9 ; 24 \mathrm{~h}$ hydrolysis). The result showed that the molecular weight of FPH ranged from $18.05 \mathrm{kDa}$ to $75.89 \mathrm{kDa}$ (Fig. 4).

Figure 4: insert here..

\section{Amino acid composition}

The amino acid composition of the FPH from parrotfish heads extracted at $\mathrm{pH} 9$ with $24 \mathrm{~h}$ hydrolysis was compared to the FPH from tuna heads (Bougatef et al., 2012) and commercial FPH (IQI, 2015) (Table 3.)

Table 3: insert here..

Parrotfish FPH consists of essential amino acids (histidine, threonine, valine, isoleucine, leucine, phenylalanine, and lysine) and non-essential amino acids (aspartic acid, glutamic acid, serine, arginine, glycine, alanine, tyrosine, and proline).

\section{Discussion}

The yield of FPH from parrotfish heads is higher than that obtained from Yellow-Spotted Trivaly fish heads (71.77\%) (Tawfik, 2009), tuna fish heads (9.85\%) (Parvathy et al., 2018), Grouper fish head (71.20) (Tawfik, 2009). The antioxidant activity of parrotfish heads was much lower than that derived from Catla fish heads (77.92\%) (Elavarasan, Kumar \& Shamasundar, 2014). Heating can be applied to increase the yield, because it allows water unbound to materials to dissipate (Khan et al., 2017). Furthermore, the longer the hydrolysis time, the higher the yield. Kim (2013) stated that the FPH yield increases as a function of time of hydrolysis until its reaches a stationary phase. The highest yield obtained in this study $(49.00 \pm 0.9 \%)$ was lower than that of tuna (60.73\%) (Ramakrishnan et al., 2013) and codfish (75\%) (Himonides Taylor \& Morris, 2011).

Compared to FPH from the heads of catfish and mackerel, the antioxidant activity of FPH from parrotfish heads was still lower (Le Vo et al., 2016; Ediriweera, Aruppala \& Abeyrathne, 2011). The size of peptides and the composition of free amino acids affect the antioxidant activity of FPH. The longer the hydrolysis time, the more abundant free amino acids become. Hydrophobic amino acids such as Pro, Leu, Ala, Trp, and Phe will increase antioxidant activity. In addition, Tyr, Met, His, and Lys are able to act as antioxidants (Le Vo et al., 2016).

The protein content of parrotfish head FPH was higher than that obtained from catfish heads (39.03\%) (Utomo, Suryaningrum \& Harianto 2014), tuna heads (28.39\%) (Ramakrishnan et al., 2013), but still lower than commercial FPH (73-75\%) (IQI, 2005). According to Nurdiani et al., 
273 (2016), the protein content of FPH can be influenced by the amount of water dehydrated from 274 the material. The Food and Agricultural Organization (2011) has categorized FPH into three 275 types; type A (protein content is more than $80 \%$ ), type B (protein content is less than $80 \%$ ), and 276 type C (low quality FPH). Based on its protein content, FPH from parrotfish heads could be 277 classified as a type B hydrolysate.

278 The fat content of parrotfish head FPH was lower than the FPH from croaker fish head waste 279 (5.1 $\pm .0 \%)$ (Amorim et al., 2016) and commercial FPH (19-22\%) (IQI, 2005). The low-fat 280 content of parrotfish head FPH was due to the low-fat content in fish head raw materials 281

282

283

284

285

286

287

288

289

290

291

292

293

294

295

296

297

298

299

300

301

302

303

304

305

306

307

308

309

310

311

312 (3.92\%). According to Peter (2003), the fat content in hydrolysate products is influenced by the characteristics of the raw materials used and the process of separating fat after hydrolysis. The fat was separated mechanically during the centrifugation process.

The ash levels were higher than that of cod head waste FPH (1\%) (Himonides Taylor \& Morris, 2011), but still met commercial FPH standards (4-7\%) (IQI, 2005). The ash content in FPH tends to increase with an increasing amount of buffer $(\mathrm{HCl}$ and $\mathrm{NaOH})$ added. According to Salamah, Nurhayati \& Widadi, (2011), high ash content in FPH was a result of the addition of alkali compounds, such as $\mathrm{NaOH}$, or acid compounds, such as $\mathrm{HCl}$, in the process of protein hydrolysis. Mixing acid and alkali compounds in the protein hydrolysate solution will cause the formation of salt compounds, which increases the ash content in protein hydrolysates. The water content of parrotfish head FPH was higher than that of cod head FPH (5\%) (Himonides Taylor \& Morris, 2011) and commercial FPH standards (3-5\%) (IQI, 2005).

The optimization result indicated that the best FPH would be produced from $\mathrm{pH} 9$ and a $24 \mathrm{~h}$ hydrolysis time. $\mathrm{pH} 9$ has previously been recorded as the best $\mathrm{pH}$ for hydrolyzing fish byproducts (Singh \& Soottawat, 2018). One parameter that should be considered during this optimization process is the low protein content; the protein content was below commercial FPH (IQI, 2005). This result was also corroborated by the DH result. Norma et al., (2005), and Hau et al., (2018), reported that a longer incubation time increased the DH.

The DH of parrotfish hydrolysate was higher than that of Nile fish heads (14.3\%) (Srikanya et al., 2017) and kurisi byproducts (15\%) (Gajanan, Elavarasan \& Shamasundar. 2016). This is possibly due to the high level of endogenous parrotfish head proteases. For the first two hours, the DH was similar from the result from Herpandi et al., (2012) and Herpandi et al., (2013), which use commercial enzymes for the hydrolysis. However, our result was lower in the third hours of hydrolysis. It is clear that the enzyme plays an important role in the DH. Furthermore, the physical structure and protein molecules, which exist in the sample, were affecting the DH (Kanu et al., 2009).

The DH affects protein molecular weight and amino acids. FPH from Nile fish had a wider range of molecular weight (14.4 to $116 \mathrm{kDa}$ ) (Tejpal et al., 2017) than that obtained in this study. The dominance of small peptides will increase the potency of the FPH as a bioactive substance. The total essential amino acids of FPH from parrotfish heads (41.69\%) approached the commercial standard of FPH (42.70\%) (IQI, 2005), but was still lower than FPH from tuna heads (46.90\%) (Bougatef et al., 2012). According to Chobert, Bertrand-Herb \& Nicolas (1998), the 
313 content of essential amino acids indicates the potential of hydrolysates to serve as a useful source 314 of nutrition. The difference in amino acid composition between hydrolysates depends on 315 differences in enzyme specificity and hydrolysis conditions.

316 The total hydrophobic amino acid content of parrotfish FPH (41\%) was higher than the FPH 317 from tuna heads (36.92\%) (Bougatef et al., 2012) and commercial FPH (29.30\%) (IQI, 2005).

318 The amino acid composition can also affect the functional properties of FPH, such as the nature 319 of the antioxidant activity. According to Zainol et al. (2003), hydrophobic amino acids (alanine, 320 leucine, and proline) have been shown to have free radical quenching activities. Hydrophobic aromatic amino acids (tyrosine and phenylalanine) can also function as antioxidants by donating

322 electrons.

323

324

325

326

327

328

329

330

331

332

333

334

335

336

337

338

339

340

341

342

343

344

345

346

347

348

349

350

351

352

Analysis of amino acids can determine the quality of FPH manufactured, specifically from the ratio of amino acids contained in these proteins (Nurilmala, Nurhayati \& Roskananda, 2018). According to Annisa, Darmanto \& Amalia, (2017), the amino acids in each fish species vary depending on internal and external factors. Internal factors include fish species, sex, age, and the reproduction phase of the fish, while external factors are typically environmental.

\section{Conclusions}

Characteristics of FPH from the heads of parrotfish (C. sordidus) were affected by the ratio of minced fish head: $\mathrm{dH}_{2} \mathrm{O}, \mathrm{pH}$, and duration of hydrolysis. The yield, antioxidant activity, protein content, ash content, and $\mathrm{DH}$ of the FPH were dependent on $\mathrm{pH}$ and time of hydrolysis. The optimum conditions for the production of FPH from parrotfish heads include a minced head: $\mathrm{dH}_{2} \mathrm{O}$ ratio of $1: 2(\mathrm{w} / \mathrm{v})$, at $\mathrm{pH} 9$, with a $24 \mathrm{~h}$ hydrolysis time. The process generated an essential amino acid profile of $41.69 \%$. To the best of our knowledge, this is the first report on the added value of $C$. sordidus heads.

\section{References}

Adrim M. 2010. Biological aspect of Parrotfish (Scaridae). Oseana 33 (1):41-50 (in Indonesian)

Amorim RG, Oliveira FC, Deschamps C, Pessatti ML. 2016. Protein hydrolysate waste of whitemouth croaker (Micropogonias furnieri) as a way of adding value to fish and reducing the environmental liabilities of the fishing industry. Journal of Aquatic Research 44 (5):967-974 DOI: 10.3856/vol44-issue5-fulltext-9.

Anil KA. 2017. Food Processing By-Products and Their Utilization. New York: John Wiley \& Sons Ltd.

AOAC. 2005. Official Methods of Analysis. Washington D.C. Association of Official Analytical Chemists.

Boogers I, Plugge W, Stokkermans YQ, Alexander L.L. 2008. Ultra-performance liquid chromatographic analysis of amino acids in protein hydrolysates using an automated precolumn derivatisation method. Duchateau Journal of Chromatography A 1189:406-409 DOI: 10.1016/j.chroma.2007.11.052. 
353

354

355

356

357

358

359

360

361

362

363

364

365

366

367

368

369

370

371

372

373

374

375

376

377

378

379

380

381

382

383

384

385

386

387

388

389

390

391
Bougatef A, Balti R, Haddar A, Jellouli K, Souissi N, Nasri M. 2012. Protein hydrolysates from bluefin tuna (Thunnus thynnus) heads as influenced by the extent of enzymatic hydrolysis. Journal Biotechnology and Bioprocess Engineering 17:841-852 DOI: 10.1007/s12257-012-0053-y.

Chen LS. 2002. Post-settlement Diet Shift of Chlorurus sordidus and Scarus schlegeli (Pisces: Scaridae). Zoological Studies 41(1): 47-58.

Chobert JM, Bertrand-Herb C, Nicolas MG. 1988. Solubility and emulsifying properties of caseins and whey proteins modified enzymatically by trypsin. Journal of Agriculture and Food Chemistry 36:883-892. DOI: 10.1021/jf00083a002.

Donkor ON, Stojanovska L, Ginn P, Ashton J, Vasiljevic T. 2012. Germinated grains sources of bioactive compounds. Food Chemistry. 135 (3): 950-959 DOI: 10.1016/j.foodchem.2012.05.058.

Ediriweera TK, Aruppala ALYH, Abeyrathne EDNS. 2019. Analysis of bioactive properties of fish protein hydrolysates from Scomber japonicus fin wastes. Journal of Technology and Value Addition 1 (1):31-45.

Elavarasan V, Kumar N, Shamasundar BA. 2017. Antioxidant and functional properties of fish protein hydrolysates from fresh water carp (catla catla) as influenced by the nature of enzyme. Journal of Food Processing and Preservation 38: 207-1214 DOI: $10.1111 /$ jfpp.12081.

Food and Agriculture Organization [FAO]. 2015. Fishery and Aquaculture Country Profiles Barbados. Available at http://www.fao.org/fishery/facp/BRB/en. (accessed 26 January 2019).

Gajanan PG, Elavarasan K, Shamasundar BA. 2016. Bioactive and functional properties of protein hydrolysates from fish frame processing waste using plant proteases. Environmental Science and Pollution Resesearch 23(24): 1-11 DOI: 10.1007/s11356016-7618-9.

Herpandi, Huda N, Adzitey F. 2011. Fish Bone and Scale as a potential Source for Halal Gelatin. Journal of Fisheries and Aquatic Science 6(4): 379-389 DOI: 10.3923/jfas.2011.379.389.

Herpandi, Huda N, Rosma A, Wan Nadiah WA. 2012. Degree of hydrolysis and free tryptophan content of Skipjack Tuna (Katsuwonus pelamis) protein hydrolysates produced with different type of industrial proteases. International Food Research Journal 19 (3): 863-867

Herpandi, Huda N, Rosma A, Wan Nadiah WA. 2013. Optimizing the enzymatic hydrolysis of skipjack tuna (Katsuwonus pelamis) dark flesh using Alcalase ${ }^{\circledR}$ enzyme: A response surface approach. Journal of Fisheries and Aquatic Science 8(4): 494-505

Hau EH, Mohd ZZ, Zuraidah N, Shaharudin NA, Zainol MK. 2018. Physicochemical properties of powdered protein hydrolysate from Yellostripe scad (Selaroides leptolepis) Fish. International Food Research Journal 25 (6):2553-2559.

Peer) reviewing PDF | (2019:09:41381:1:0:REVIEW 7 Nov 2019) 
392

393

394

395

396

397

398

399

400

401

402

403

404

405

406

407

408

409

410

411

412

413

414

415

416

417

418

419

420

421

422

423

424

425

426

427

428

429

430

Himonides AT, Taylor AKD, Morris AJ. 2011. Enzymatic hydrolysis of fish frames using pilot plant scale systems. Journal Food and Nutrition Sciences 2:586-593.

DOI:10.4236/fns.2011.26082

Hoyle NT, Merritt JH. 1994. Quality of fish-protein hydrolysates from herring (Clupea harengus). Journal of Food Science 59 (1):76-79 DOI:10.1111/j.13652621.1994.tb06901.x.

International Quality Ingredients [IQI]. 2005. Fish protein hydrolysate. Available at http://www. eyequye.nl (accessed 26 January 2019).

Jeevitha K, Priya M, Khora SS. 2014. Antioxidant activity of fish protein hydrolysates from Sardinella longiceps. International Journal of Drug Development and Research 6 (4):137-145.

Kanu PJ, Kanu JB, Edward HS, Joseph BAK, Philip MP, Zhou HM. 2009. Optimization of Enzymatic hydrolysis of defatted sesame flour by different proteases and their effect on the functional properties of the resulting protein hydrolysate. American Journal of Food technology 4 (6):226-240 DOI: 10.3923/ajft.2009.226.240.

Khan MIH, Szilvia AN, Mark W, Mohammad UJH. 2017. Experimental investigation of bound and free water transport process during drying of hygroscopic food material. International Journal of Thermal Sciences 117: 266-273 DOI: 10.1016/j.ijthermalsci.2017.04.006.

Kim SK. 2013. Marine Proteins and Peptides: Biological Activities and Applications. New York: John Wiley \& Sons Ltd.

Kim SK, Mendis E. 2006. Bioactive compounds from marine processing byproducts-a review. Food Research International 39 (4):383-393. DOI: 10.1016/j.foodres.2005.10.010.

Laemmli UK. 1970. Cleavage of structural proteins during assembly of the head of bacteriophage T4. Nature 227:680-685 DOI:10.1038/227680a0.

Le Vo TD, Nguyen TTH, Phan DV, Nguyen HDM, Tran HQ. 2016. Investigation of antioxidant activity of the hydrolysate derived from Tra catfish byproducts using Alcalase 2.4 L FG for application as a natural antioxidant ingredient. Journal Science and Technology Development 19 (6): 109-121 DOI: 10.32508/stdj.v19i3.577.

Ministry of Marine Affair and Fisheries. 2019. Production and Price of Fish in Indonesia. Available at http://pipp.djpt.kkp.go.id/profil_pelabuhan/1304/produksi_harga (accessed 24 October 2019).

Norma I, Jamilah B, Saari N, Yakakob BCM. 2005. Optimization of Hydrolysis condition for the production of Treadfin Bream (Nemipterus japonicus) hydrolysate by Alcalase. Journal of Muscle Foods 16:87-102 DOI: 10.1111/j.1745-4573.2005.07404.x.

Nurdiani R, Dissanayake M, Street WE, Donkor ON, Singh TK dan Vasiljevic T. 2016. In vitro study of selected physiological and physicochemical properties of fish protein hydrolysates from 4 Australian fish species. International Food Research Journal. 23 (5): 2042-2053. 
431

432

433

434

435

436

437

438

439

440

441

442

443

444

445

446

447

448

449

450

451

452

453

454

455

456

457

458

459

460

461

462

463

464

465

466

467

468

469

Nurilmala M, Nurhayati T, Roskananda R. 2018. By product of Catfish fillet Industry for protein hydrolysate. Jurnal Pengolahan Hasil Perikanan Indonesia 21 (2):287-294 DOI: 10.17844/jphpi.v21i2.23083 (in Indonesian)

Parvathy U, Nizam KM, Zynudheen AA, Ninan G, Panda SK, Ravishankar CN. 2018. Characterization of fish protein hydrolysate from red meat of Euthynnus affinis and its application as an antioxidant in iced sardine. Journal of Scientific and Industrial Research 77: 111-119.

Peter JB. 2003. Properties of different fish processing by-products from pollock, cod and salmon. Journal of Food Processing Preservation 27: 101-116 DOI: 10.1111/j.17454549.2003.tb00505.x.

Qiao M, Tu M, Wang Z, Mao F, Chen H, Qin L, Du M. 2018. Identification and Antithrombotic Activity of Peptides from Blue Mussel (Mytilus edulis) Protein. International journal of molecular sciences 19 (1): 138 DOI: 10.3390/ijms19010138.

Ramakrishnan VV, Ghaly AE, Brooks MS, Budge SM. 2013. Extraction of proteins from mackerel fish processing waste using alcalase enzyme. Journal of Bioprocessing and Biotechniques 3 (2):1-9 DOI: 10.4172/2155-9821.1000130.

Sabtecha B, Jayapriya J, Tamilselvi A. 2014. Extraction and characterization of proteolytic enzymes from fish visceral waste: Potential applications as destainer and dehairing agent. International Journal of ChemTech Research 6 (10):4504-4510.

Salamah E, Nurhayati T, Widadi IR. 2011. Production and Characterization of Protein Hydrolysates from African Catfish (Clarias gariepinus) using Papain. Jurnal Pengolahan Hasil Perikanan Indonesia 15 (1): 9-16 DOI: 10.17844/jphpi.v15i1.5328 (in Indonesian)

Singh A, Benjakul S. 2018. Proteolysis and its control using protease inhibitors in fish and fish products. Comprehensive Reviews in Food Science and Food Safety 17: 496-509 DOI: 10.1111/1541-4337.12337.

Srikanya A, Dhanapal K, Sravani K, Madhavi K, Kumar GP. 2017. A study on optimization of fish protein hydrolysate preparation by enzymatic hydrolysis from tilapia fish waste mince. International Journal Microbial 6 (12):3220-3229 DOI: 10.20546/ijcmas.2017.612.375.

Tawfik MS. 2009. Proximate Composition and Fatty Acids Profiles in Most Common Available Fish Species in Sausi Market. Asian Journal of Clinical Nutrition 1(1): 50-57

Tejpal CS, Lekshmi RGK, Asha KK, Anandan R, Chatterjee NS. 2017. Antioxidant, functional properties and amino acid composition of pepsin-derived protein hydrolysates from whole tilapia waste as influenced by pre-processing ice storage. Journal of Food Science and Technology 1 (1):11-29 DOI: 10.1007/s13197-017-2897-9.

Utomo BSB, Suryaningrum TD, Harianto HR. 2014. Optimization of enzymatic hydrolisis of protein hydrolisate processing from waste of catfish filet production. Squalen Bulletin of Marine and Fisheries Postharvest and Biotechnology 9(3):107-114 DOI: 10.15578 /squalen.v9i3.79.

Peer) reviewing PDF | (2019:09:41381:1:0:REVIEW 7 Nov 2019) 
470 Wu, TH, Ning JD, Stine JJ, Bechtel PJ. 2011. Nutritional and chemical composition of by-

471

472

473

474

475

476

477

478

479

480 product fractions produced from wet reduction of individual red salmon (Oncorhynchus nerka) heads and viscera. Journal of Aquatic Food Product Technology 20:183-195 DOI: 10.1080/10498850.2011.557524.

Yang P, Ke H, Hong P, Zeng S, Cao W. 2011. Antioxidant activity of bigeye tuna (Thunnus obesus) head protein hydrolysate prepared with Alcalase. International Journal of Food Science and Technology 46 (12):2460-2466 DOI: 10.1111/j.1365-2621.2011.02768.x.

Zainol MK, Abd-hamid A, Yusof S, Muse R. 2003. Antioxidative activity and total phenolic compounds of leaf, root and petiole of four accessions of Centella asiatica (L.) Urban. Food Chemistry 81:575-581 DOI: 10.1016/S0308-8146(02)00498-3. 
Figure 1

FPH from Parrotfish Head

(A) Formed layers after centrifugation. (B) Collected soluble protein layer (C). dried FPH.

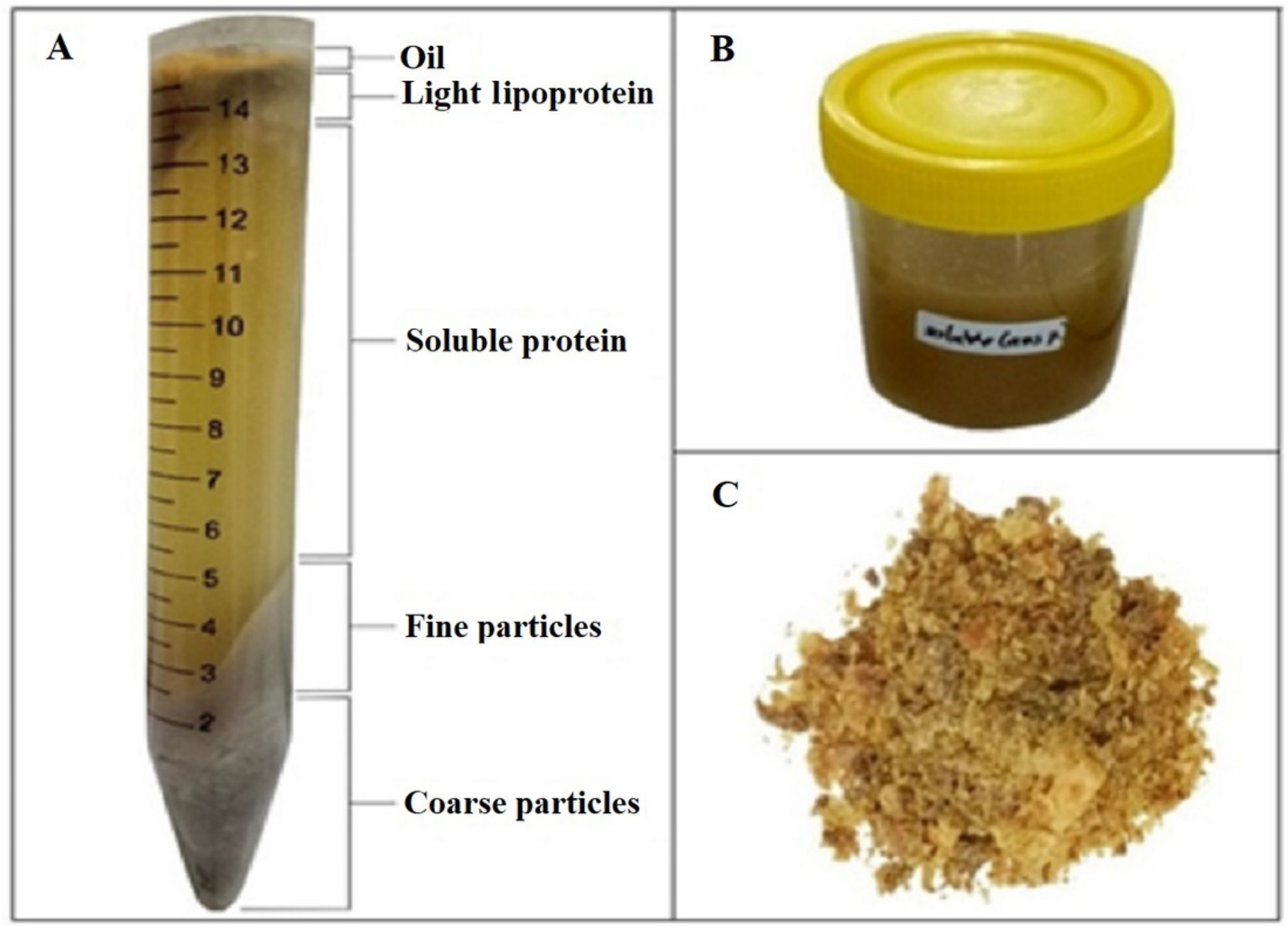


Figure 2

Yield and antioxidant activity of FPH




Figure 3

Overlaid Contour Plot for optimum FPH

Countur Plot of Degree of Hy; Protein; Fat; Ash; Water; ...
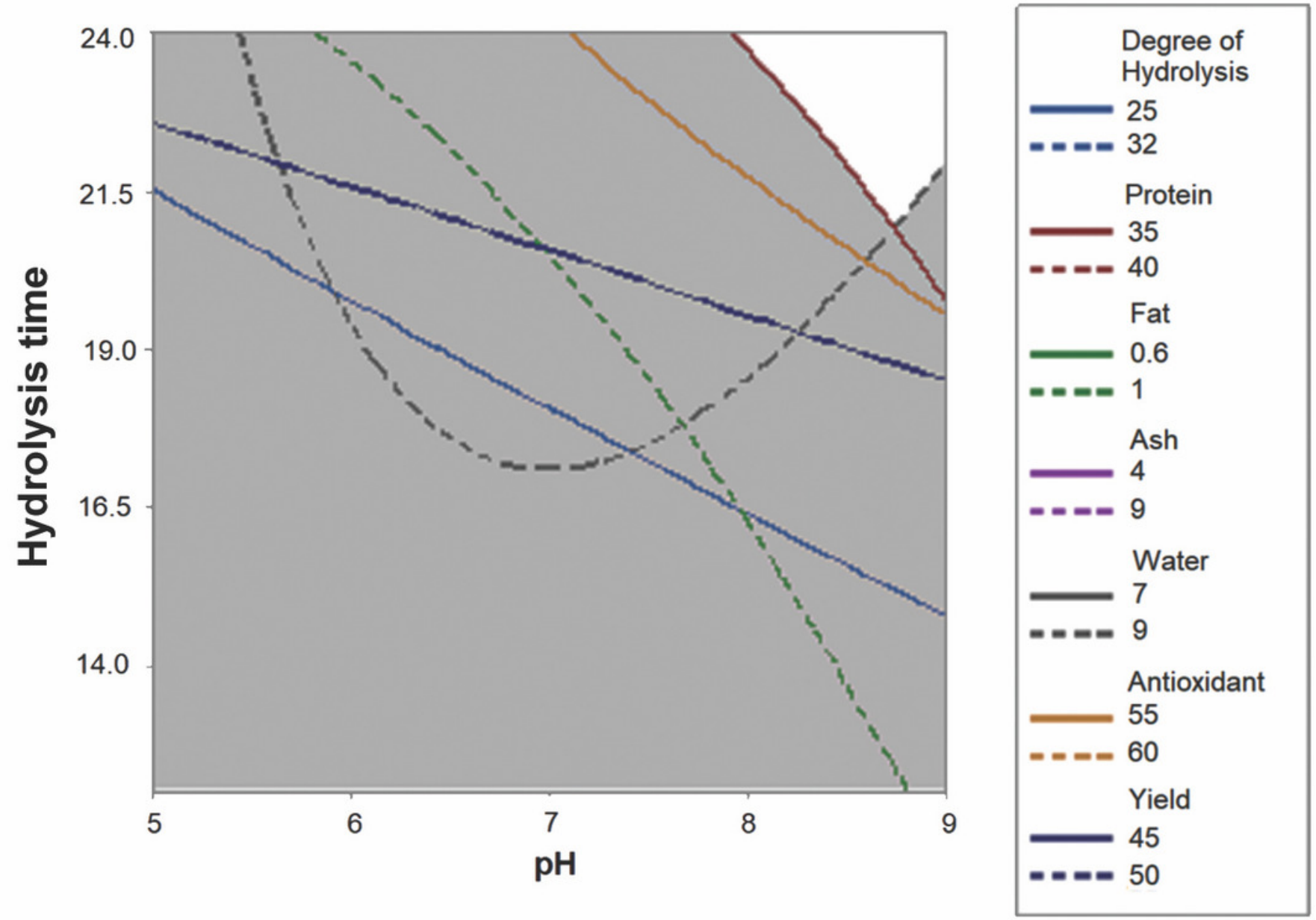
Figure 4

Molecular weight distribution of parrotfish FPH.

(A) Sample (pH 9 and 24 h). (M) Molecular weight of protein standard. 
A $\quad \mathbf{M}(\mathrm{kDa})$

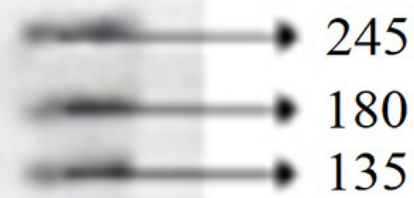

100

75
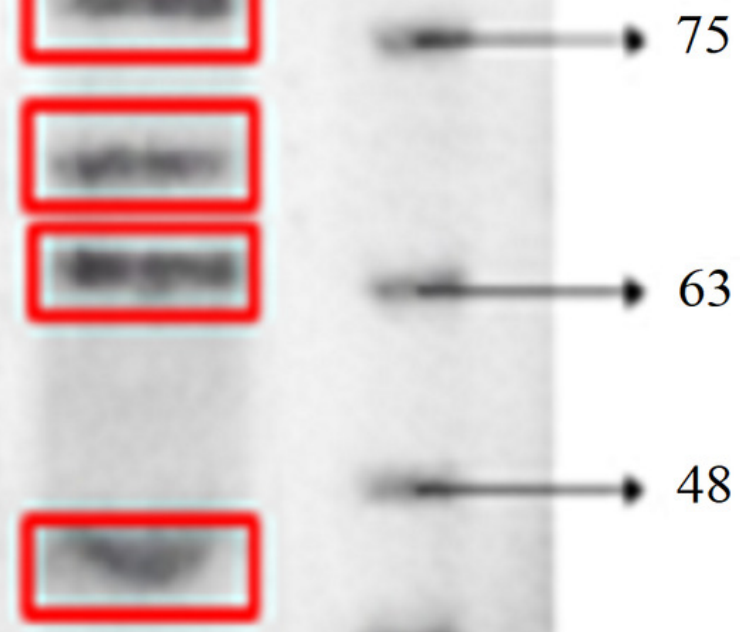

35

25

20
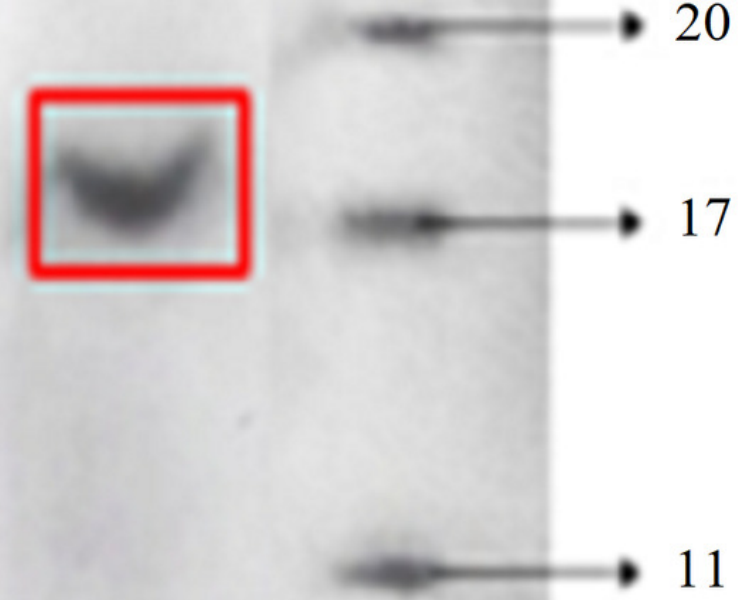


\section{Table 1 (on next page)}

Proximate composition of minced Parrotfish, Salmon, and Nile.

*) this study, **) Wu et al., 2011, ***) Kefas et al., 2014 
1 Table 1: Proximate composition of minced Parrotfish, Salmon, and Nile.

\begin{tabular}{|c|c|c|c|}
\hline Parameter & Parrotfish *) & Salmon **) & Nile $* * *)$ \\
\hline Carbohydrate $(\%)$ & $0.52 \pm 0.13$ & - & 37.78 \\
\hline Protein $(\%)$ & $20.37 \pm 2.33$ & 11.90 & 29.80 \\
\hline Fat $(\%)$ & $3.92 \pm 0.38$ & 17.40 & 3.10 \\
\hline Water $(\%)$ & $71.68 \pm 1.87$ & 65.90 & 5.70 \\
\hline Ash (\%) & $4.19 \pm 0.66$ & 4.30 & 21.80 \\
\hline
\end{tabular}

2 *) this study, **) Wu et al., 2011, ***) Kefas et al., 2014 


\section{Table 2 (on next page)}

Characteristics of FPH from parrotfish heads with different $\mathrm{pH}$ and hydrolysis duration

${ }^{*}$ Control was done without $\mathrm{pH}$ adjustment $(\mathrm{pH} 6.4)$.

**Control time for hydrolysis. 
1 Table 2: Characteristics of FPH from parrotfish heads with different $\mathrm{pH}$ and hydrolysis duration

\begin{tabular}{|c|c|c|c|c|c|c|c|c|c|c|c|c|}
\hline \multirow{2}{*}{ Parameter } & \multicolumn{3}{|c|}{ Control* } & \multicolumn{3}{|c|}{5} & \multicolumn{3}{|c|}{7} & \multicolumn{3}{|c|}{9} \\
\hline & $0 * *$ & 12 & 24 & $0 * *$ & 12 & 24 & $0 * *$ & 12 & 24 & $0 * *$ & 12 & 24 \\
\hline yield & $5.78 \pm 0.85^{\mathrm{a}}$ & $39.15 \pm 0.87^{b}$ & $47.48 \pm 1.29^{\mathrm{cd}}$ & $5.50 \pm 2.03^{\mathrm{a}}$ & $37.73 \pm 0.92^{\mathrm{b}}$ & $45.4 \pm 1.17^{\mathrm{c}}$ & $4.96 \pm 0.72^{\mathrm{a}}$ & $36.36 \pm 1.03^{\mathrm{b}}$ & $48.37 \pm 0.63^{\text {cd }}$ & $6.58 \pm 2.13^{\mathrm{a}}$ & $40.28 \pm 0.63^{\mathrm{bc}}$ & $49.04 \pm 0.90^{\mathrm{e}}$ \\
\hline antioxidant & $6.22 \pm 2.28^{\mathrm{a}}$ & $43.79 \pm 1.13^{\mathrm{b}}$ & $54.58 \pm 1.31^{\mathrm{d}}$ & $6.53 \pm 0.67^{\mathrm{a}}$ & $44.5 \pm 1.5^{\mathrm{b}}$ & $49.24 \pm 1.35^{\mathrm{c}}$ & $5.89 \pm 1.47^{\mathrm{a}}$ & $43.34 \pm 0.62^{\mathrm{b}}$ & $56.31 \pm 0.78^{\mathrm{e}}$ & $5.69 \pm 4.57^{\mathrm{a}}$ & $48.85 \pm 1.57^{\mathrm{c}}$ & $58.20 \pm 0.55^{\mathrm{f}}$ \\
\hline $\mathrm{DH}$ & $0.28 \pm 0.17^{\mathrm{a}}$ & $21.46 \pm 1.71^{\mathrm{c}}$ & $28.09 \pm 1.75^{\mathrm{e}}$ & $0.59 \pm 0.12^{\mathrm{a}}$ & $22.47 \pm 0.73^{\mathrm{cd}}$ & $24.77 \pm 1.69^{\mathrm{cd}}$ & $0.44 \pm 0.05^{\mathrm{a}}$ & $19.76 \pm 0.75^{\mathrm{b}}$ & $29.60 \pm 1.65^{\mathrm{e}}$ & $0.26 \pm 0.11^{\mathrm{a}}$ & $24.04 \pm 1.36^{\mathrm{cd}}$ & $30.65 \pm 1.82^{\text {ef }}$ \\
\hline protein & $51.81 \pm 2.45^{\mathrm{bc}}$ & $48.98 \pm 2.45^{\mathrm{b}}$ & $63.16 \pm 1.11^{\mathrm{de}}$ & $49.3 \pm 2.89^{b}$ & $50.72 \pm 0.89^{\mathrm{cbc}}$ & $59.69 \pm 0.89^{d}$ & $49.3 \pm 2.00^{\mathrm{b}}$ & $44.89 \pm 1.56^{\mathrm{a}}$ & $64.26 \pm 0.89^{\mathrm{e}}$ & $48.98 \pm 2.48^{\mathrm{b}}$ & $55.13 \pm 1.78^{c}$ & $69.15 \pm 1.11^{\mathrm{f}}$ \\
\hline Fat & $5.72 \pm 1.01$ & $1.2 \pm 0.14^{\mathrm{a}}$ & $1 \pm 0.28^{\mathrm{a}}$ & $5.88 \pm 2.99$ & $1.35 \pm 0.35^{\mathrm{a}}$ & $1.02 \pm 0.23^{\mathrm{a}}$ & $5.49 \pm 0.70$ & $1.25 \pm 0.5^{\mathrm{a}}$ & $0.89 \pm 0.25^{\mathrm{a}}$ & $5.52 \pm 2.12$ & $0.97 \pm 0.47^{\mathrm{a}}$ & $0.68 \pm 0.13^{\mathrm{a}}$ \\
\hline ash & $7.00 \pm 2.83^{b}$ & $4.55 \pm 0.35^{\mathrm{a}}$ & $4.85 \pm 0.35^{\mathrm{a}}$ & $6.5 \pm 0.71^{\mathrm{ab}}$ & $6.8 \pm 0.69^{\mathrm{ab}}$ & $7.04 \pm 1.06^{\mathrm{b}}$ & $8.00 \pm 1.41^{\mathrm{bc}}$ & $5.05 \pm 0.64^{\mathrm{a}}$ & $5.5 \pm 0.7^{\mathrm{a}}$ & $7.00 \pm 1.25^{\mathrm{b}}$ & $8.56 \pm 0.78^{c}$ & $8 \pm 0.17 \mathrm{c}$ \\
\hline Water & $8.38 \pm 0.74^{\mathrm{ab}}$ & $8.39 \pm 0.74^{\mathrm{ab}}$ & $7.82 \pm 0.55^{\mathrm{a}}$ & $8.64 \pm 0.98^{\mathrm{ab}}$ & $8.63 \pm 0.99^{\mathrm{ab}}$ & $8.24 \pm 1.06^{\mathrm{ab}}$ & $8.41 \pm 0.67^{\mathrm{ab}}$ & $8.41 \pm 0.67^{\mathrm{ab}}$ & $7.25 \pm 1.06^{a}$ & $9.00 \pm 0.71^{\mathrm{b}}$ & $9.01 \pm 0.71^{\mathrm{b}}$ & $7.85 \pm 1.2^{\mathrm{a}}$ \\
\hline
\end{tabular}

*Control was done without $\mathrm{pH}$ adjustment ( $\mathrm{pH} 6.4$ ).

$3 \quad * *$ Control time for hydrolysis. 
Table 3 (on next page)

Comparison of Amino acid composition of several FPH 
1 Tabel 3: Comparison of Amino acid composition of several FPH

\begin{tabular}{|c|c|c|c|c|}
\hline No. & Amino acids & $\begin{array}{l}\text { FPH from } \\
\text { Parrotfish } \\
\text { head (\%) }\end{array}$ & $\begin{array}{l}\text { FPH from Tuna } \\
\qquad(\%)\end{array}$ & $\begin{array}{c}\text { Commercial } \\
\text { FPH (\%) }\end{array}$ \\
\hline 1. & L-Ser & 1.81 & 5.18 & 4.90 \\
\hline 2. & L- Glu & 14.43 & 11.20 & 14.00 \\
\hline 3. & L-Phe & 5.53 & 06.18 & 3.70 \\
\hline 4. & L- Ile & 4.34 & 4.83 & 4.00 \\
\hline 5. & L- Val & 5.38 & 7.49 & 4.90 \\
\hline 6. & L- Ala & 7.41 & 2.88 & 7.30 \\
\hline 7. & L- Arg & 6.12 & 11.53 & 6.80 \\
\hline 8. & L-Gly & 7.63 & 3.32 & 11.00 \\
\hline 9. & L- Lys & 8.3 & 10.23 & 7.50 \\
\hline 10. & L- Asp & 11.06 & 9.91 & 9.50 \\
\hline 11. & L- Leu & 8.48 & 6.48 & 6.50 \\
\hline 12. & L- Pro & 5.64 & 3.62 & - \\
\hline 13. & L-Tyr & 4.22 & 5.44 & 2.90 \\
\hline 14. & L- Thr & 6.80 & 2.17 & 4.40 \\
\hline 15. & L-His & 2.85 & 9.52 & 2.60 \\
\hline \multicolumn{2}{|c|}{ Total Essential Amino Acid } & 41.69 & 46.90 & 42.70 \\
\hline \multicolumn{2}{|c|}{$\begin{array}{l}\text { Total Hydrophobic Amino Acid } \\
\text { (HAA) }\end{array}$} & 41.00 & 36.92 & 29.30 \\
\hline
\end{tabular}

